\title{
Osjetljivost gimnazijalaca na svjetlosno onečišćenje u Republici Hrvatskoj
}

\author{
Hrvoje Grofelnik \\ Sveučilište u Rijeci, Fakultet za menadžment u turizmu i ugostiteljstvu, \\ Opatija, Hrvatska \\ e-mail: hrvoje.grofelnik@fthm.hr
}

\section{Marko Miočić}

Prva riječka hrvatska gimnazija, Rijeka, Hrvatska

e-mail: marko.miocic1@skole.hr

\section{Tomislav Golubić \\ Prirodoslovna škola Vladimira Preloga, Zagreb, Hrvatska e-mail: tomislav.golubic11@skole.hr}

SAŽETAK Ovaj je rad rezultat anketnog istraživanja na nacionalnoj razini po pitanju poznavanja problematike, svjesnosti i stavova učenika gimnazijskih programa u Hrvatskoj prema problemu svjetlosnog onečišćenja. Razlike u komunalnoj infrastrukturi u Hrvatskoj su velike, te se odražavaju i u aspektu svjetlosnog onečišćenja. Provedeno istraživanje nije bilo usmjereno ka usporedbi stanja u prostoru po pitanju svjetlosnog onečišćenja, već na poznavanje problematike, te su izdvojeni subjektivni stavovi i percepcije gimnazijalaca prema utjecaju svjetlosnog onečišćenja na okoliš. Kako bi se dobio što objektivniji uvid, istraživanje je oslonjeno na kvantitativne metode te su rezultati prikazani i interpretirani uz pomoć deskriptivne i induktivne statistike.

Rezultati pokazuju homogenost ispitanika na nacionalnoj razini u poznavanju problematike, svjesnosti i stavovima o svjetlosnom onečišćenju. Usporedbom učenika iz ruralnih i urbanih prostora po pitanju svjesnosti o svjetlosnom onečišćenju pokazalo se da ne postoje veće razlike i da je opća svijest relativno visoka. Usporedba učenika iz ruralnih i urbanih prostora po pitanju prevencije svjetlosnog onečišćenja također pokazuje da ne postoje veće razlike te da je spremnost na djelovanje visoka. Ipak, uočene su i određene razlike između urbane i ruralne populacije učenika po pitanju procjene utjecaja svjetlosnog onečišćenja na okoliš. Učenici iz urbanih područja procjenjuju da je utjecaj svjetlosnog onečišćenja na okoliš neutralan ili malen, za razliku od učenika iz ruralnih područja, koji su više skloni procijeniti utjecaj svjetlosnog onečišćenja u kategoriji malog i vrlo malog utjecaja.

Ključne riječi: održivi razvoj, okoliš, zaštita okoliša, svjetlosno onečišćenje, obrazovanje, gimnazija. 


\section{Uvod}

Razmatranje problema svjetlosnog onečišćenja na globalnoj razini prvenstveno je potaknuto iz krugova znanstvene zajednice astronoma 1970-ih godina (Riegel, 1973.), a kasnije se interes za navedenu tematiku proširio u domene održivog razvoja, zaštite okoliša i zdravlja ljudi (Chepesiuk, 2009.). Od početne faze uočavanja problema svjetlosnog onečišćenja pa do danas mogu se izdvojiti različite etape razvoja spoznaja i svijesti o samom fenomenu. Značajan korak u globalnom priznavanju problematike i budućem djelovanju predstavlja tzv. Starlight deklaracija (Declaration in Defence of the Night Sky and the Right to Starlight) usvojena u La Palmi 2007. godine, koja promovira pravo čovjeka na zvjezdano nebo. Od početka uočavanja fenomena pa do danas jasno je da su negativni utjecaji svjetlosnog onečišćenja vidljivi u različitim prostornim i društvenim aspektima. Negativan utjecaj svjetlosnog onečišćenja posebice je vidljiv u mnogim urbanim sredinama, u kojima je sve teže razlikovati dan od noći, a životni ritam više ne prati prirodni ciklus dan - noć, što uzrokuje niz ekoloških, zdravstvenih i socioloških negativnih utjecaja (Longcore, 2004.; Navara i Nelson, 2007.). Važno je uočiti da se fenomen svjetlosnog onečišćenja, koji je desetljećima bio vezan za umjetnu rasvjetu u urbanim područjima, s porastom životnog standarda i procesima suburbanizacije sve više širi i na ruralna područja, što je globalno posebice izraženo u područjima visokog životnog standarda (slika 1).

Slika 1.

Povezanost urbanih područja sa svjetlosnim onečišćenjem

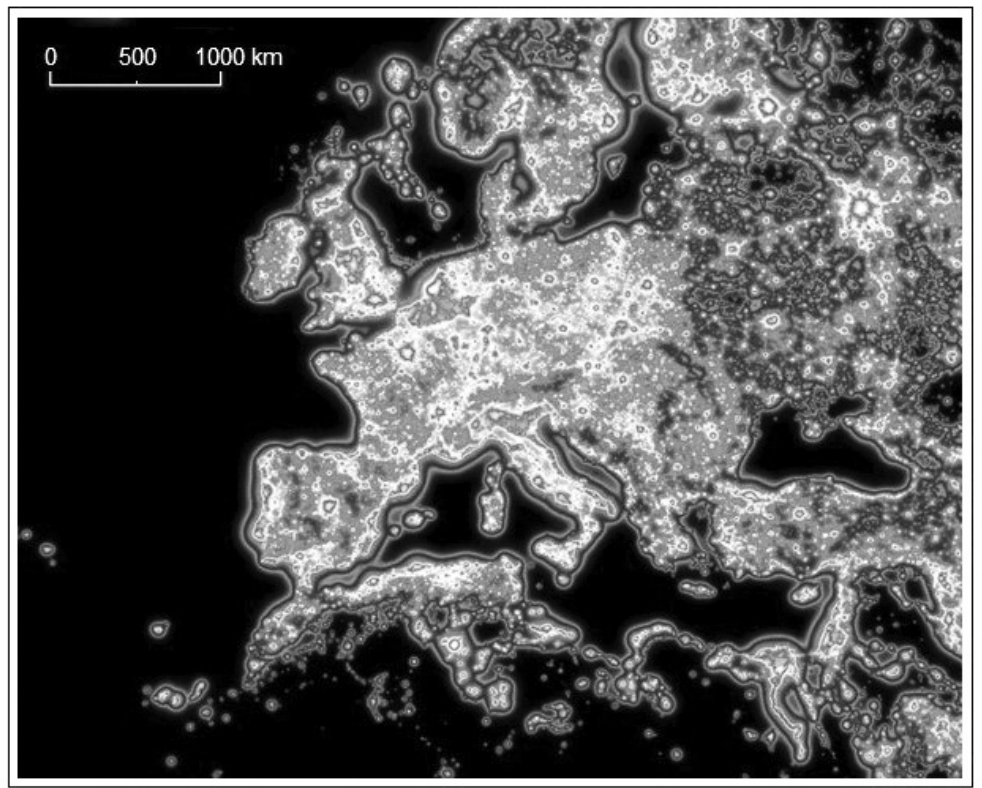

Izvor: https://www.lightpollutionmap.info/ 
U razmatranju fenomena svjetlosnog onečišćenja treba istaknuti nehomogenost među akterima vezanima za samu problematiku, a prema tome i pozicije, odnosno načine djelovanja u društvu, kao što su znanstvenici, stručnjaci, tvrtke, institucije, državna uprava, udruge - građanske inicijative i pojedinci. Također, moguće je primijetiti i nehomogenost s obzirom na poznavanje problematike kao preduvjeta za razvoj svjesnosti o negativnim učincima ovog vida onečišćenja, što je temelj za proaktivne stavove i daljnje djelovanje u društvu.

Interes za istraživanje područja utjecaja čovjeka na okoliš te specifično teme svjetlosnog onečišćenja bio je začetak ovog rada. S obzirom na to da načini djelovanja društva na okoliš u budućnosti najvećim dijelom počivaju na generacijama koje se danas oblikuju unutar sustava obrazovanja, artikuliran je problem istraživanja i sama populacija (uzorak) na kojoj će istraživanje biti provedeno. Stoga je cilj ovog rada bio ispitati poznavanje problematike, svjesnost i stavove današnjih gimnazijalaca po pitanju svjetlosnog onečišćenja. Dalje su oblikovana istraživačka pitanja, koja su razrađena oblikovanjem anketnog upitnika. Kako bi se dobio što objektivniji uvid i izvukli odgovarajući zaključci, analiza rezultata dobivenih anketiranjem provedena je uz pomoć kvantitativnih metoda te deskriptivne i induktivne statistike.

Istraživanjem svjesnosti, stavova i poznavanja problematike od strane gimnazijalaca u Republici Hrvatskoj o problemu svjetlosnog onečišćenja nastojala se utvrditi edukacijska baza budućih generacija, koje bi trebale napraviti nužan iskorak u transformaciji i oblikovanju kvalitetnog komunalnog okoliša. Naime, bez obzira na vidljivo povećanje društvene svjesnosti o tom problemu, jasno je da sam problem urbanizacijom, industrijalizacijom te povećanjem svjetske populacije i rastom životnog standarda zahvaća sve veća područja te se najčešće manifestira u većem intenzitetu (Doll i sur., 2006.).

\section{Pregled povijesti istraživanja i razvoja područja}

Općedruštveni trend povećanja svjesnosti i djelovanja po pitanju problematike svjetlosnog onečišćenja vidljiv je i iz donošenja zakonskih akata u Republici Hrvatskoj. Tako je 2019. godine stupio na snagu Zakon o zaštiti od svjetlosnog onečišćenja (NN 14/19) te je 2020. donesen i Pravilnik o zonama rasvijetljenosti, dopuštenim vrijednostima rasvjetljavanja i načinima upravljanja rasvjetnim sustavima (NN 128/2020). U svjetskoj stručnoj i znanstvenoj literaturi u zadnjih tridesetak godina vidljiv je pozitivan trend objavljivanja radova iz područja svjetlosnog onečišćenja (slika 2). 
Slika 2.

Broj objavljenih radova s temom svjetlosnog onečišćenja u WoSCC bazi od 1991. do 2021. godine

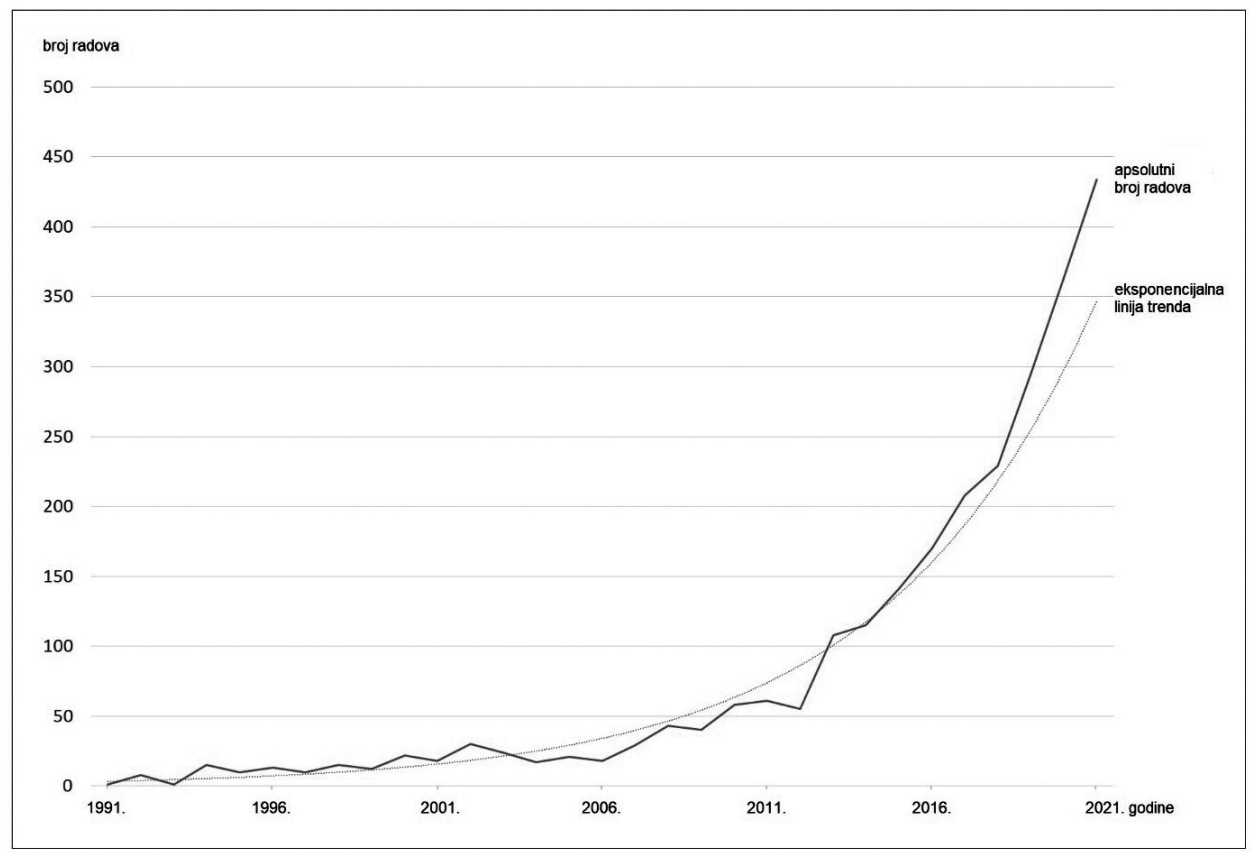

Izvor: prema podacima iz WoSCC baze, svibanj 2021. godine

Prostorna zastupljenost istraživanja koja obuhvaćaju različite aspekte svjetlosnog onečišćenja od 1970-ih se godina proširila iz visokorazvijenih zemalja svijeta i na prostore brzog industrijskog razvoja, kao što je primjerice Kina, što je vrlo važno zbog velikog utjecaja brzorastućih gospodarstava na globalne društvene trendove i stanje u okolišu. Za daljnju analizu unutar ovoga rada nije nužno dati pregled svih stručnih i znanstvenih radova iz istraživanog područja, ali ne mogu se zaobići neke od publikacija koje su obilježile razvoj znanstvenog područja, kao što su: Light Pollution - Responses and Remedies iz 2002.; Light Pollution Handbook iz 2004. i Light pollution: definition, legislation, measurement, modeling and environmental effects iz 2007. godine.

Također je u predmetnom području istraživanja potrebno uočiti diferencijaciju prema užem predmetu istraživanja, te je moguće izdvojiti značajnije radove iz područja astronomije i obrazovanja: Metaxa (2010.); radove iz područja obrazovanja: Pearcy (2001.), Özyürek i Aydin (2015.); ekologije: Hölker i sur., (2010.a), Hölker i sur., (2010.b), Gaston i sur. (2012.), Gaston i sur. (2013.); područja utjecaja na zdravlje: Chepesiuk (2009.), Falchi i sur. (2011.), Coogan i sur. (2020.); turizma: Lima i sur. (2016.) te prikaz analize opće percepcije javnosti o svjetlosnom onečišćenju kao dijelu ukupnog utjecaja na okoliš: Carlsen i Bruggemann (2020.). 
U Hrvatskoj se od 1990-ih godina u znanstvenim i stručnim krugovima počelo govoriti o problemu svjetlosnog onečišćenja. Potrebno je posebno naglasiti entuzijazam i djelovanje udruga i pojedinaca u zadnjih dvadesetak godina koji rade na senzibilizaciji ukupnog društva iz želje za porastom opće svijesti po pitanju svjetlosnog onečišćenja, među kojima se posebno ističe djelovanje Znanstveno edukacijskog centra u Višnjanu pod vodstvom Korada Korlevića. Za postizanje dugoročnog cilja od presudne je važnosti educirati što širi krug aktera u društvu, a posebice mlađih generacija, što je ostvarivo aktualizacijom obrazovnih sadržaja iz područja zaštite okoliša i održivog razvoja kroz obavezni osnovnoškolski i dalje srednjoškolski obrazovni program. Stanje svjesnosti društva o problemu svjetlosnog onečišćenja s vremenom se poboljšava, ali nije na zadovoljavajućoj razini ni iz edukacijskog ni provedbenog aspekta. U zadnjih desetak godina na prostoru Hrvatske vidljivo je povećanje interesa za problematiku svjetlosnog onečišćenja. Uz nekolicinu provedenih empirijskih istraživanja svjetlosnog onečišćenja koja su dala konkretne rezultate, vidljivo je i širenje interesa za tematiku među institucijama, udrugama i pojedincima različitih struka. Stručni i znanstveni radovi u trenutku pisanja ovog rada (lipanj 2021. godine) navedeni na Portalu hrvatskih znanstvenih i stručnih časopisa (Hrčak) koji obrađuju temu svjetlosnog onečišćenja su: Fonović (2008.), Martinis i Mikuta-Martinis (2008.), Andreić i sur. (2011.), Andreić, Andreić i Pavić (2012.), Sharma i sur. (2015.), Andreić (2018.), Fuk (2019.), Krajnović (2020.a), Krajnović (2020.b), Pavlić i Andreić (2020.). Navedeni radovi donose rezultate znanstvenih i stručnih istraživanja s konkretnim podacima o svjetlosnom onečišćenju neba na pojedinim lokacijama te obrađuju teme od općih edukacijskih sadržaja, utjecaja svjetlosnog onečišćenja na prirodu i ljudsko zdravlje, utjecaja svjetlosnog onečičćenja na zastiranje pogleda u nebo i utjecaja na astronomska promatranja do specifičnih tema kao što su javna sigurnost ili pak astroturizam.

\section{Metodologija istraživanja}

Istraživački proces kojim su dobivene spoznaje predstavljene u ovom radu započeo je pilot-istraživanjem Grofelnika (2019.), koje je nastavljeno 2020. godine, čime je definirano područje, tema i teorijski okvir. U idućoj fazi definiran je problem istraživanja, određen je cilj, formulirana su istraživačka pitanja te su postavljene hipoteze. Cilj ovog istraživanja bio je ispitati poznavanje problematike, svjesnost i stavove današnjih gimnazijalaca po pitanju svjetlosnog onečišćenja. $U$ odnosu na cilj istraživanja izrađen je upitnik te je određena populacija, odnosno anketni uzorak kojim je bilo moguće ostvariti zadani cilj. Provedbom ankete prikupljeni su izvorni podaci, koji su dalje analizirani, izvučeni su zaključci u odnosu na postavljena istraživačka pitanja te su testirane postavljene hipoteze. Rad u konačnici donosi opis stanja po pitanju poznavanja problematike, svjesnosti i stavova učenika na razini nacionalnog uzorka te prepoznaje dvije skupine učenike s razlikama prema uočavanju problema svjetlosnog onečišćenja. 
U početnoj fazi istraživanja indirektnim metodama pretražene su baze podataka WoSCC, Scopus, Crosbi i Hrčak te su prikupljeni relevantni podaci iz znanstvene i stručne literature. Također su proučeni i planski dokumenti kao i zakoni te pravilnici Republike Hrvatske koji se bave problematikom svjetlosnog onečišćenja.

Direktno prikupljanje podataka za potrebe istraživanja provedeno je internetskim anketiranjem putem alata MS Forms tijekom školske godine 2020./2021. Upitnik korišten tijekom anketiranja sastojao se od 20 čestica (pitanja) podijeljenih u dvije skupine (sociodemografska i tematska pitanja). Tematskim pitanjima u upitniku vršila se identifikacija svjesnosti, poznavanja problematike i stavova ciljane gimnazijske populacije o problematici svjetlosnog onečišćenja atmosfere prema mjestu stanovanja. Reprezentativnost anketiranog uzorka na nacionalnoj razini Republike Hrvatske temeljila se na metodi stratificiranog slučajnog uzorka, a obuhvatila je uvjetno homogenu populaciju učenika gimnazijskih programa (od 15. do 19. godine starosti, čime su obuhvaćeni učenici svih četiriju razreda gimnazije). Nadalje, reprezentativnost anketiranog uzorka osigurana je na način da je anketa provedena u osam gradova koji su ujedno i županijska središta. Prostorna reprezentativnost uzorka dobivena je na način da su četiri županijska središta iz kontinentalnog dijela Hrvatske (Zagreb, Varaždin, Požega i Virovitica), dok su preostala četiri iz primorskog dijela Hrvatske (Split, Rijeka, Zadar i Pazin). S obzirom na to da se anketom ciljalo na reprezentativnost uzorka i po osnovi funkcionalnih i infrastrukturnih obilježja naselja prema mjestu prebivališta ispitanika, odabrana su urbana nodalno-funkcionalna središta (obrazovna središta), čiji ispitanici ne predstavljaju samo urbane cjeline, već i okolno gravitacijsko suburbano i ruralno područje. U konačnici je uspješno anketirano 774 učenika, te je reprezentativnost uzorka na nacionalnoj razini vrlo visoka, odnosno omjer je urbane prema ruralnoj populaciji u Republici Hrvatskoj oko 54 : 46, dok je u anketiranom uzorku dobiven omjer $59: 41$.

Analitički dio rada utemeljen je na izvornim statističkim podacima dobivenim obradom anketnih upitnika. Tijekom analize podataka korištene su deskriptivne kvantitativne metode, matematičko-statističke metode analize izvornih podataka, a za testiranje hipoteza korištena je metoda z-testa. Z-test metodom testirane su početna i alternativna hipoteza, odnosno izvršena je komparacija dvaju nezavisnih uzoraka $s$ normalnom distribucijom, kojima je određena značajnost razlika srednjih vrijednosti.

Deskriptivni dio kvantitativne analize podataka dobivenih istraživanjem predočen je u radu kombinacijom tablica i dijagrama po izdvojenim statističkim pokazateljima. Sintezom ukupnih podataka dobiven je cjelovit uvid u stanje odnosa po pitanju poznavanja problematike, svjesnosti i stavova gimnazijalaca na nacionalnoj razini. Navedeno je poslužilo kao temelj za analizu i izdvajanje zaključaka o uočenom stanju na razini čitavog uzorka kao i uočenim razlikama unutar uzorka. 


\section{Rezultati istraživanja}

Analiza rezultata istraživanja slijedila je koncept kojim su se, nakon početnog snimanja stanja u odnosu na problem istraživanja, razmatrala istraživačka pitanja i testirale hipoteze. Prvi set istraživačkih pitanja odnosio se na problematiku na nacionalnoj razini, odnosno na uzorak kao cjelinu (istraživačka pitanja: I-1, I-2 I-3 i I-4), dok se u drugom setu istraživačkih pitanja (istraživačka pitanja: I-5, I-6, I-7) ušlo u analizu prema izdvojenim prostornim skupinama unutar anketiranog uzroka, koji je podijeljen na dvije nezavisne skupine učenika iz urbanih odnosno ruralnih prostora.

Kako bi se dobio uvid u stanje u prostoru po pitanju potencijalnog svjetlosnog onečišćenja, ali i da bi se potvrdilo je li zahvaćeni uzorak reprezentativan za daljnju analizu (izloženost svjetlosnom onečišćenju), ispitanici su odgovarali na pitanje: „Imate li javnu rasvjetu u vašoj ulici?" Rezultati su pokazali da je na ukupnom uzorku od 774 ispitanika (učenika) na pitanje potvrdno odgovorilo 98,06 \% ispitanika. Razdvajanjem ispitanika na ciljane skupine iz urbanih prostora utvrđen je postotak pokrivenosti javnom rasvjetom od 98,90 \%, dok je u ruralnom prostoru pokrivenost 96,88 \%. Iz navedenog je vidljivo da ne postoji značajna razlika između ispitanika iz urbanih i ruralnih prostora po pitanju osnovne komunalne infrastrukture koja potencijalno stvara svjetlosno onečíšćenje te se pristupilo daljnjoj analizi rezultata istraživanja. Navedeni je podatak od izuzetne važnosti s obzirom na kasniju analizu, koja posebno stavlja naglasak na razlike između ispitanika koji žive u ruralnim i urbanim prostorima.

U idućem koraku analize ciljalo se na utvrđivanje osnovnog odnosa ispitanika prema javnoj rasvjeti te im je postavljeno pitanje: „Osjećate li se sigurnije noću uz upaljenu rasvjetu?" Ispitanici su dalje podijeljeni na dvije skupine prema odgovoru na postavljeno pitanje te su navedeni rezultati uspoređeni s pitanjima koja su ciljala na stavove vezane uz proaktivnost u prevenciji svjetlosnog onečišćenja, koja su glasila: „Smatrate li da bi količinu svjetlosti uličnih rasvjetnih tijela i reklama trebalo regulirati (smanjiti) tijekom noćnih perioda?" $i$,Smatrate li da bi količinu svjetlosti uličnih rasvjetnih tijela i reklama trebalo regulirati (smanjiti) tijekom noćnih perioda?“"

Tablica 1.

Odnos ispitanika prema javnoj rasvjeti na nacionalnoj razini.

\begin{tabular}{|c|c|c|c|c|c|}
\hline \multicolumn{6}{|c|}{ Osjećate li se sigurnije noću uz upaljenu rasvjetu? } \\
\hline \multicolumn{3}{|c|}{$\begin{array}{c}\text { DA } \\
88,50 \%\end{array}$} & \multicolumn{3}{|c|}{$\begin{array}{c}\text { NE } \\
11,50 \%\end{array}$} \\
\hline \multicolumn{3}{|c|}{$\begin{array}{l}\text { Smatrate li da bi količinu svjetlosti uličnih rasvjetnih } \\
\text { tijela i reklama trebalo regulirati (smanjiti) tijekom } \\
\text { noćnih perioda? }\end{array}$} & \multicolumn{3}{|c|}{$\begin{array}{l}\text { Smatrate li da bi količinu svjetlosti uličnih rasvjetnih } \\
\text { tijela i reklama trebalo regulirati (smanjiti) tijekom } \\
\text { noćnih perioda? }\end{array}$} \\
\hline $\begin{array}{c}\text { DA } \\
69,05 \%\end{array}$ & $\begin{array}{c}\text { NE } \\
12,41 \%\end{array}$ & $\begin{array}{l}\text { NE ZNAM } \\
18,54 \%\end{array}$ & $\begin{array}{c}\text { DA } \\
70,79 \%\end{array}$ & $\begin{array}{c}\text { NE } \\
13,48 \%\end{array}$ & $\begin{array}{l}\text { NE ZNAM } \\
15,73 \%\end{array}$ \\
\hline
\end{tabular}

Izvor: anketa 
Iz rezultata moguće je pozitivno povezati osjećaj sigurnosti ispitanika s prisutnošću javne rasvjete u prostoru u kojem žive. Dalje se testirala spremnost za proaktivno djelovanje po pitanju smanjivanja svjetlosnog onečišćenja analizom odgovora (tablica 1), te je vidljivo da su ispitanici spremni žrtvovati dio osjećaja osobne sigurnosti smanjivanjem, odnosno regulacijom javne rasvjete i reklama tijekom noćnih perioda.

\subsection{Prvo istraživačko pitanje}

\section{I-1: Uočavaju li učenici svjetlosno onečišćenje u prostoru u kojem žive?}

Pitanje I-1 bilo je usmjereno prema uočavanju svjetlosnog onečišćenja na razini cije$\log$ nacionalnog uzorka. Namjera je bila ispitati imaju li učenici razvijenu svijest po pitanju svjetlosnog onečišćenja u prostoru u kojem žive te kako procjenjuju utjecaj izvora svjetlosnog onečišćenja na okoliš, odnosno koliko su senzibilizirani s obzirom na svjetlosno onečišćenje. Pitanja koja su bila oblikovana za navedeno glasila su: „Jeste li uočili da određena rasvjetna tijela svijetle iznad razine horizonta i time nepotrebno rasvjetljavaju nebo?“ i „Kako biste procijenili utjecaj javne rasvjete i reklama na svjetlosno onečišćenje u vašoj ulici gdje stanujete?"

$\mathrm{Na}$ razini ukupnog nacionalnog uzorka 63,31 \% učenika odgovorilo je da uočavaju kako određena rasvjetna tijela svijetle iznad razine horizonta i time nepotrebno rasvjetljavaju nebo, što pokazuje relativnu svjesnost ispitanika o problemu svjetlosnog onečišćenja u njihovom životnom prostoru. Udio učenika koji ne uočavaju svjetlosno onečišćenje može ukazivati na nedovoljnu usmjerenost na probleme koje za okoliš i zdravlje uzrokuje nepravilno postavljena rasvjeta ili je pak rasvjeta u njihovom životnom prostoru postavljena u skladu s propisima koji preveniraju svjetlosno onečišćenje. S obzirom na to da u je u Hrvatskoj česta situacija da se komunalna infrastruktura, konkretno javna rasvjetna tijela popravljaju i zamjenjuju novijima i postavljaju propisno na parcijalan način, odnosno bez rekonstrukcije čitavih ulica ili naselja, česta je pojava da jedna uz drugu stoje javna rasvjetna tijela posve različitih karakteristika po pitanju svjetlosnog onečišćenja. Stoga je trenutno nemoguće na nacionalnoj razini istraživanja ulaziti u detaljnije analize, što i nije cilj ovog rada. U budućim etapama istraživanja moguće je uz odgovarajuće preinake upitnika i uvid u konkretan prostor na razini studija slučaja istražiti odnose lokalne populacije prema svjetlosnom onečišćenju na lokalnoj razini.

Kako bi se dalje usporedilo ima li razlike između onih koji su potvrdno odgovorili i onih koji su negativno odgovorili, uzorak se podijelio na navedene dvije skupine te su obje uspoređene s obzirom na njihovu procjenu utjecaja javne rasvjete i reklama na okoliš. 
Tablica 2.

Svjesnost i procjena utjecaja svjetlosnog onečišćenja na okoliš - nacionalna razina uzorka

\begin{tabular}{|l|c|c|c|c|c|}
\hline & \multicolumn{4}{|c|}{ Kako biste procijenili utjecaj javne rasvjete i reklama na svjetlosno } \\
onečišćenje u vašoj ulici gdje stanujete?
\end{tabular}

Izvor: anketa

Vidljivo je da učenici koji uočavaju da određena rasvjetna tijela stvaraju svjetlosno onečišćenje isto tako procjenjuju kako je utjecaj svjetlosnog onečišćenja u njihovoj ulici stanovanja veći od učenika koji ne uočavaju svjetlosno onečišćenje. U tablici 2 istaknuti su udjeli prema ekstremima na skali procjene utjecaja svjetlosnog onečišćenja, prema kojima je vidljivo da se vrijednosti u uspoređenim skupinama razlikuju za skoro dvostruku vrijednost. Usporedbom navedenih odgovora na pitanja iz tablice 2 može se zaključiti da kod ispitanika postoji pozitivna korelacija između uočavanja svjetlosnog onečišćenja i procjene utjecaja na okoliš. Oni učenici koji uočavaju svjetlosno onečišćenje ujedno procjenjuju da je utjecaj javne rasvjete i reklama na okoliš veći.

\subsection{Drugo istraživačko pitanje}

\section{I-2: Posjeduju li učenici znanja o svjetlosnom onečišćenju?}

Pitanje I-2 bilo je usmjereno ka uvidu u učenička znanja o problematici svjetlosnog onečišćenja na razini cijelog nacionalnog uzorka. Namjera je bila ispitati imaju li učenici praktična znanja po pitanju svjetlosnog onečišćenja u prostoru u kojem žive te znaju li kome bi trebali prijaviti izvore svjetlosnog onečišćenja. Pitanje za provjeru znanja o prepoznavanju izvora svjetlosnog onečišćenja bilo je oblikovano grafički s prikazom različito oblikovanih javnih rasvjetnih tijela, među kojima su učenici odabirali.

Slika 1.

Odgovori na pitanje „Koje od skiciranih uličnih rasvjetnih tijela stvara najmanje svjetlosno onečišćenje?“

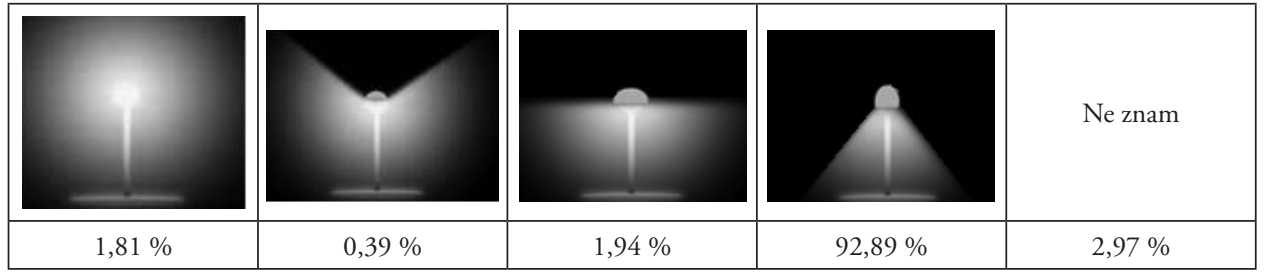

Izvor: anketa 
Pitanje kojim se željelo ispitati znaju li učenici kome prijaviti svjetlosno onečišćenje bilo je otvorenog tipa sa slobodnim unosom te je glasilo: „Znate li kome treba prijaviti svjetlosno onečišćenje?" Na navedeno pitanje odgovori su bili različito formulirani te su izdvojene skupine odgovora, a najveći udio učenika, 95,09\%, nije ponudio odgovor ili je napisao „ne“ ili „ne znam“.

Rezultati jasno pokazuju kako učenici znaju koji oblik rasvjetnog tijela stvara najmanje svjetlosno onečišćenje. Vidljivo je također da i oni učenici koji su u nekim drugim pitanjima pokazali određenu nesigurnost po pitanju poznavanja problematike svjetlosnog onečišćenja na grafički postavljeno pitanje odgovaraju u velikom postotku točno, što je vjerojatno rezultat intuicije u kontaktu s postavljenim grafičkim pitanjem. Bez obzira na jasno prepoznavanje rasvjetnih tijela koja stvaraju svjetlosno onečišćcnje, potpuno je suprotna situacija po pitanju znanja učenika o tome kome bi ga mogli/ trebali prijaviti. Navedeni problem očito je rezultat manjkavosti u edukaciji i općoj niskoj razini komunalne pismenosti opće javnosti.

\subsection{Treće istraživačko pitanje}

\section{I-3: Jesu li učenici svjesni utjecaja svjetlosnog onečišćenja?}

Pitanje I-3 bilo je usmjereno prema ukupnom nacionalnom uzorku. Namjera je bila ispitati postoji li svijest kod učenika o utjecaju svjetlosnog onečišćenja u prostoru u kojem žive te postoji li razlika između svjesnosti i stava prema teoretskom utjecaju svjetlosnog onečišćenja na okoliš (životni ciklus ljudi, životinja i biljaka) i utjecaju na osobnoj razini vezanom uz utjecaj ulične rasvjete i reklama na noćni odmor ispitanika.

Na opće pitanje „Smatrate li da zbog ulične rasvjete i reklama dolazi do poremećaja u životnom ciklusu ljudi, životinja i biljaka?" 74,29 \% učenika odgovorilo je potvrdno, dok je na osobno pitanje „Smatrate li da svjetlost ulične rasvjete i reklame tijekom noći utječe na kvalitetu vašeg sna?" potvrdno odgovorilo $35,79 \%$ učenika.

Iz rezultata je vidljivo kako su učenici svjesni teoretskog utjecaja svjetlosnog onečišćenja na okoliš i ljude, ali kada je u pitanju osobni stav prema konkretnom utjecaju javne rasvjete i reklama na njihov san, tada je tek malo više od trećine ispitanika potvrdno odgovorilo. Kod analize tih odgovora otvara se daljnje pitanje jesu li ispitanici zaista malo izloženi svjetlosnom onečišćenju ili ga nisu dovoljno svjesni. Navedeno bi trebalo dalje istražiti u obliku studije slučaja na nižoj prostornoj razini, gdje se može konkretno napraviti instrumentalno mjerenje lokalnog svjetlosnog onečišćenja te nakon toga provesti anketa o svjesnosti i stavovima na promatranom području. 


\section{4. Četvrto istraživačko pitanje}

\section{I-4: Imaju li učenici proaktivne stavove po pitanju prevencije svjetlosnog onečišcenja?}

Pitanje I-4 bilo je usmjereno prema uočavanju spremnosti na prevenciju svjetlosnog onečišćenja na razini cijelog nacionalnog uzorka. Namjera je bila ispitati imaju li učenici razvijenu svijest po pitanju svjetlosnog onečišćenja u prostoru u kojem žive te koliko su spremni biti proaktivni po pitanju smanjenja javne rasvjete i svjetlećih/ osvjetljenih reklamnih tijela. Pitanja koja su bila oblikovana za navedeno glasila su: „Smatrate li da bi reklame na gradskim fasadama trebalo ugasiti tijekom noćnih perioda?" $i$ „Smatrate li da bi količinu svjetlosti uličnih rasvjetnih tijela i reklama trebalo regulirati (smanjiti) tijekom noćnih perioda?“

Kod pitanja koje je bilo isključivo, odnosno gdje se radilo o potpunom gašenju javne rasvjete i reklama učenici su bili nižeg stupnja potpore, dok je pristup koji uključuje regulaciju svjetlosnog onečišćenja tijekom noćnih perioda pokazao veći stupanj prihvaćanja i manje neodlučnih (tablica 3).

Tablica 3.

Spremnost na prevenciju svjetlosnog onečišćenja

\begin{tabular}{|l|c|c|c|}
\hline \multirow{2}{*}{ Pitanje } & \multicolumn{2}{|c|}{ Odgovor } \\
\cline { 2 - 4 } & DA & NE & NE ZNAM \\
\hline $\begin{array}{l}\text { Smatrate li da bi reklame na gradskim fasadama trebalo ugasiti } \\
\text { tijekom noćnih perioda? }\end{array}$ & $59,91 \%$ & $13,05 \%$ & $28,04 \%$ \\
\hline $\begin{array}{l}\text { Smatrate li da bi količinu svjetlosti uličnih rasvjetnih tijela i } \\
\text { reklama trebalo regulirati (smanjiti) tijekom noćnih perioda? }\end{array}$ & $69,25 \%$ & $12,53 \%$ & $18,22 \%$ \\
\hline
\end{tabular}

Izvor: anketa

\subsection{Peto istraživačko pitanje}

I-5: Postoji li razlika u svjesnosti o svjetlosnom onečišcenju između učenika iz ruralnih u odnosu na učenike koji žive u urbanim područjima?

Pitanje I-5 bilo je usmjereno prema svjesnosti učenika po pitanju utjecaja svjetlosnog onečišćenja na okoliš. Namjera je bila utvrditi moguće razlike u svjesnosti između onih učenika koji žive u ruralnim u odnosu na učenike iz urbanih područja.

Rezultati usporedbe učenika iz ruralnih i urbanih prostora po pitanju svjesnosti o utjecaju svjetlosnog onečišćenja na okoliš pokazuju da između tih skupina učenika ne 
postoje veće razlike te da je opća svijest o utjecaju svjetlosnog onečišćenja na okoliš relativno visoka (tablica 4 ).

Tablica 4.

Utjecaj svjetlosnog onečišćcnja na okoliš - izdvojene prostorne skupine urbano/ruralno

\begin{tabular}{|l|c|c|c|c|}
\hline \multirow{2}{*}{ Pitanje } & \multicolumn{2}{|c|}{$\begin{array}{c}\text { Učenici iz urbanih } \\
\text { područja }\end{array}$} & \multicolumn{2}{|c|}{$\begin{array}{c}\text { Učenici iz ruralnih } \\
\text { područja }\end{array}$} \\
\cline { 2 - 5 } & DA & NE & DA & NE \\
\hline $\begin{array}{l}\text { Smatrate li da zbog ulične rasvjete i reklama dolazi do } \\
\text { poremećaja u životnom ciklusu ljudi, životinja i biljaka? } \\
\text { - po prostornim skupinama urbano - ruralno }\end{array}$ & $72,69 \%$ & $27,31 \%$ & $76,56 \%$ & $23,44 \%$ \\
\hline
\end{tabular}

Izvor: anketa

\section{6. Šesto istraživačko pitanje}

I-6: Postoji li razlika u spremnosti na prevenciju svjetlosnog onečišćenja između učenika iz ruralnih u odnosu na učenike koji žive u urbanim područjima?

Pitanje I-6 bilo je usmjereno prema uočavanju stavova učenika u kontekstu spremnosti na prevenciju svjetlosnog onečišćenja. Namjera je bila ispitati postoje li razlike u stavovima urbane u odnosu na ruralnu populaciju učenika po pitanju svjetlosnog onečišćenja u prostoru u kojem žive te jesu li spremni biti proaktivni po pitanju smanjenja javne rasvjete i svjetlećih reklamnih tijela. Pitanja koja su bila oblikovana za navedeno glasila su: „Smatrate li da bi reklame na gradskim fasadama trebalo ugasiti tijekom noćnih perioda?“ i „Smatrate li da bi količinu svjetlosti uličnih rasvjetnih tijela i reklama trebalo regulirati (smanjiti) tijekom noćnih perioda?“

Rezultati usporedbe učenika iz ruralnih i urbanih prostora po pitanju proaktivnosti, odnosno spremnosti na potpuno gašenje ili smanjivanje svjetlosnog onečišćenja tijekom noćnih perioda, pokazuju da između tih skupina učenika ne postoje veće razlike te da je opća spremnost na djelovanje u zaštiti okoliša od svjetlosnog onečišćenja relativno visoka i kreće se od $57,49 \%$ pa do 70,63 \%, ovisno o pitanju i skupini ispitanika. Kod pitanja koje je bilo isključivo, odnosno gdje se radilo o potpunom gašenju javne rasvjete i reklama učenici su bili nižeg stupnja potpore, dok je pristup koji uključuje regulaciju svjetlosnog onečišćenja tijekom noćnih perioda imao više pristaša te je bilo manje neodlučnih (tablica 5). 
Tablica 5.

Stavovi i spremnost učenika po pitanju prevencije svjetlosnog onečišćenja - izdvojene prostorne skupine urbano/ruralno

\begin{tabular}{|l|c|c|c|c|c|c|}
\hline \multirow{2}{*}{ Pitanje } & \multicolumn{2}{|c|}{ Učenici iz urbanih područja } & \multicolumn{2}{|c|}{ Učenici iz ruralnih područja } \\
\cline { 2 - 7 } & DA & NE & NE ZNAM & DA & NE & NE ZNAM \\
\hline $\begin{array}{l}\text { Smatrate li da bi reklame na gradskim } \\
\text { fasadama trebalo ugasiti tijekom noćnih } \\
\text { perioda? }\end{array}$ & $57,49 \%$ & $13,22 \%$ & $29,29 \%$ & $60,94 \%$ & $12,81 \%$ & $26,25 \%$ \\
\hline $\begin{array}{l}\text { Smatrate li da bi količinu svjetlosti } \\
\text { uličnih rasvjetnih tijela i reklama trebalo } \\
\text { regulirati (smanjiti) tijekom noćnih } \\
\text { perioda? }\end{array}$ & $68,29 \%$ & $12,11 \%$ & $19,60 \%$ & $70,63 \%$ & $13,12 \%$ & $16,25 \%$ \\
\hline
\end{tabular}

Izvor: anketa

\subsection{Sedmo istraživačko pitanje}

I-7: Postoji li razlika u percepciji utjecaja svjetlosnog onečišćenja na okoliš između učenika iz ruralnih u odnosu na učenike koji žive u urbanim područjima?

Pitanje I-7 bilo je usmjereno prema procjeni utjecaja javne rasvjete i reklama na svjetlosno onečišćenje. Namjera je bila ispitati postoje li razlike u subjektivnom doživljaju utjecaja javne rasvjete i reklama na okoliš urbane u odnosu na ruralnu populaciju učenika. Pitanje koje je bilo oblikovano za navedeno glasilo je: „Kako biste procijenili utjecaj javne rasvjete i reklama na svjetlosno onečišćenje u vašoj ulici gdje stanujete?“

\section{Slika 3.}

Procjene utjecaja javne rasvjete i reklama na svjetlosno onečišćenje - izdvojene prostorne skupine urbano/ruralno

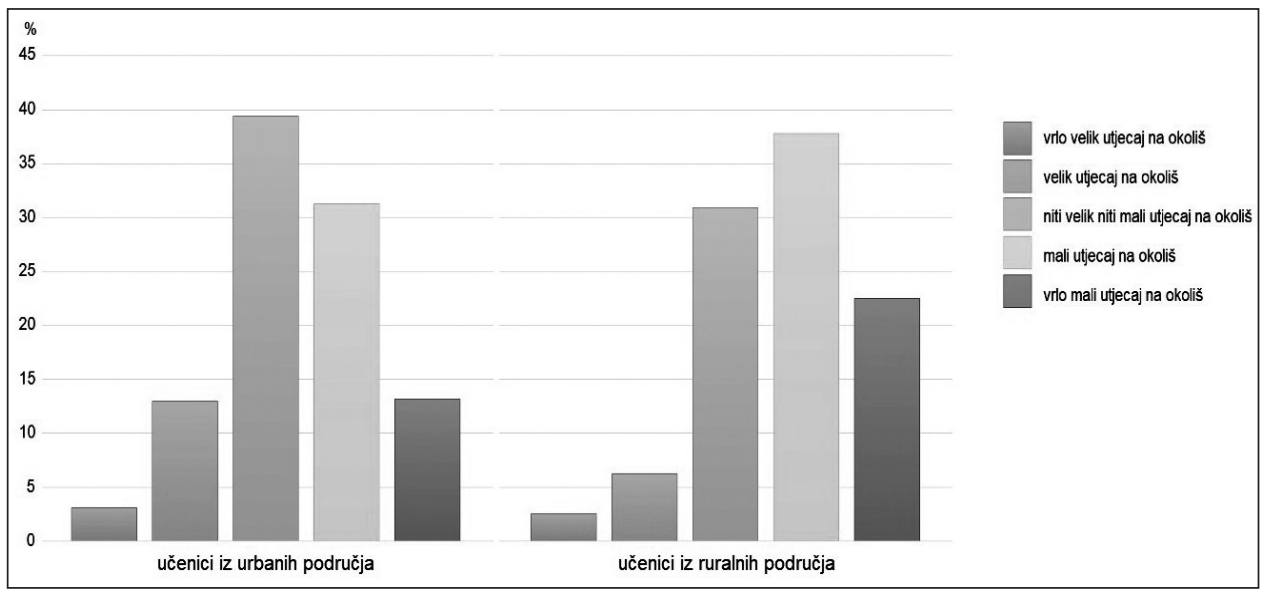

Izvor: anketa 
Učenici iz urbanih područja prema srednjoj vrijednosti na Likertovoj skali od 1 do 5 imaju srednju vrijednost od 3,385, što znači da u prosjeku procjenjuju da je utjecaj svjetlosnog onečišćenja na okoliš prema mjestu stanovanja neutralan ili malen. Za razliku od navedenog, učenici iz ruralnih područja imaju srednju vrijednost od 3,716 (slika 3) te su više skloni procijeniti utjecaj svjetlosnog onečišćenja u svom okolišu u kategoriji malog i vrlo malog utjecaja.

Iz opisanih razlika moglo bi se zaključiti da su učenici iz ruralnih područja manje izloženi svjetlosnom onečišćenju, te posljedično procjenjuju da je utjecaj javne rasvjete i reklama na okoliš u njihovom životnom prostoru manji. To je generalno u skladu s prostornim intenzitetom svjetlosnog onečišćenja u Hrvatskoj, što je vidljivo i iz karata svjetlosnog onečišćenja kao što je primjerice slika 1. Opisana razlika između ispitanika iz urbanih i ruralnih područja također bi mogla biti i posljedica ukupno manje izloženosti ispitanika negativnim utjecajima u okolišu (višim stupnjem očuvanosti okoliša), koja je rezultirala manjom usredotočenošću na problematiku onečišćenja okoliša i manjom osjetljivošću po pitanju percepcije svjetlosnog onečišćenja (zanemarivanjem problematike).

Kako bi se utvrdila valjanost zaključka kako postoji statistički značajna razlika između učenika iz urbanih i ruralnih sredina po pitanju percepcije utjecaja svjetlosnog onečišćenja na okolišs, proveden je z-test velikih nezavisnih uzoraka.

Tablica 6.

Pitanje kojim se mjerila razlika između učenika iz urbanih i ruralnih prostora

\begin{tabular}{|c|c|c|c|c|}
\hline \multicolumn{5}{|c|}{ Kako biste procijenili utjecaj javne rasvjete i reklama na svjetlosno onečišćenje u vašoj ulici gdje stanujete? } \\
\hline 1 & 2 & 3 & 4 & 5 \\
\hline $\begin{array}{c}\text { Vrlo velik utjecaj na } \\
\text { okoliš }\end{array}$ & $\begin{array}{c}\text { Velik utjecaj na } \\
\text { okoliš }\end{array}$ & $\begin{array}{c}\text { Niti velik niti mali } \\
\text { utjecaj na okoliš }\end{array}$ & $\begin{array}{c}\text { Mali utjecaj na } \\
\text { okoliš }\end{array}$ & $\begin{array}{c}\text { Vrlo mali utjecaj na } \\
\text { okoliš }\end{array}$ \\
\hline
\end{tabular}

Izvor: anketa

Testirana je početna, nul-hipoteza, koja je glasila: $\mu_{u}=\mu_{r}$, odnosno $\mu_{u}-\mu_{r}=0$.

$\mathrm{H}_{0}-\mathrm{Ne}$ postoji statistički značajna razlika između uzoraka ispitanika urbane i ruralne populacije učenika po pitanju procjene utjecaja javne rasvjete i reklama na svjetlosno onečišćenje.

Alternativna hipoteza glasila je: $\mu_{u} \neq \mu_{r}$.

$\mathrm{H}_{\mathrm{a}}$ - Postoji statistički značajna razlika između uzoraka ispitanika urbane i ruralne populacije učenika po pitanju procjene utjecaja javne rasvjete i reklama na svjetlosno onečišćenje. 
Opis uzorka i postavke z-testa:

$N_{u}$ - broj ispitanika iz (nezavisni uzorak) urbanog prostora, $\mathrm{N}_{\mathrm{u}}=454$

$N_{r}$ - broj ispitanika iz (nezavisni uzorak) ruralnog prostora, $\mathrm{N}_{\mathrm{r}}=320$

$\bar{X} \mathrm{u}$ - srednja vrijednost uzorka urbanog prostora

$\bar{X} \mathrm{r}$ - srednja vrijednost uzorka ruralnog prostora

$\alpha=0,01$ (pouzdanost testa na razini od $99 \%$, odnosno razina pogreške od $1 \%$ ).

Vrijednost $\mathrm{z}$ (prema standardiziranoj tablici z vrijednosti) za potvrđivanje $\mathrm{H}_{0}$ trebala bi biti između -2,576 i 2,576 kako bi se s pouzdanošću od $99 \%$ potvrdila početna hipoteza, koja tvrdi da ne postoji statistički značajna razlika između uzoraka ispitanika urbane i ruralne populacije.

$\sigma_{\mathrm{u}}=1,414$ (standardna devijacija - urbano), $\sigma_{\mathrm{r}}=0,707$ (standardna devijacija - ruralno).

Izračun: $\mathrm{z}=\frac{(\bar{X} u-\bar{X} r)-\left(\mu_{u}-\mu_{r}\right)}{\sqrt{\frac{S D u^{2}}{N_{u}}-\frac{S D r^{2}}{N_{r}}}}=\frac{(\bar{X} u-\bar{X} r)-0}{\sqrt{\frac{S D u^{2}}{N_{u}}-\frac{S D r^{2}}{N_{r}}}}=\frac{(3,385-3,716)-0}{\sqrt{\frac{1,414^{2}}{454}-\frac{0,707^{2}}{320}}}=\frac{-0,331}{\sqrt{\frac{1,999}{454}-\frac{0,499}{320}}}=\frac{-0,331}{\sqrt{0,0059}}=-4,298$

Slika 4.

Prikaz rezultata z-testa - izdvojene prostorne skupine urbano/ruralno

normalna distribucija - veliki uzorak

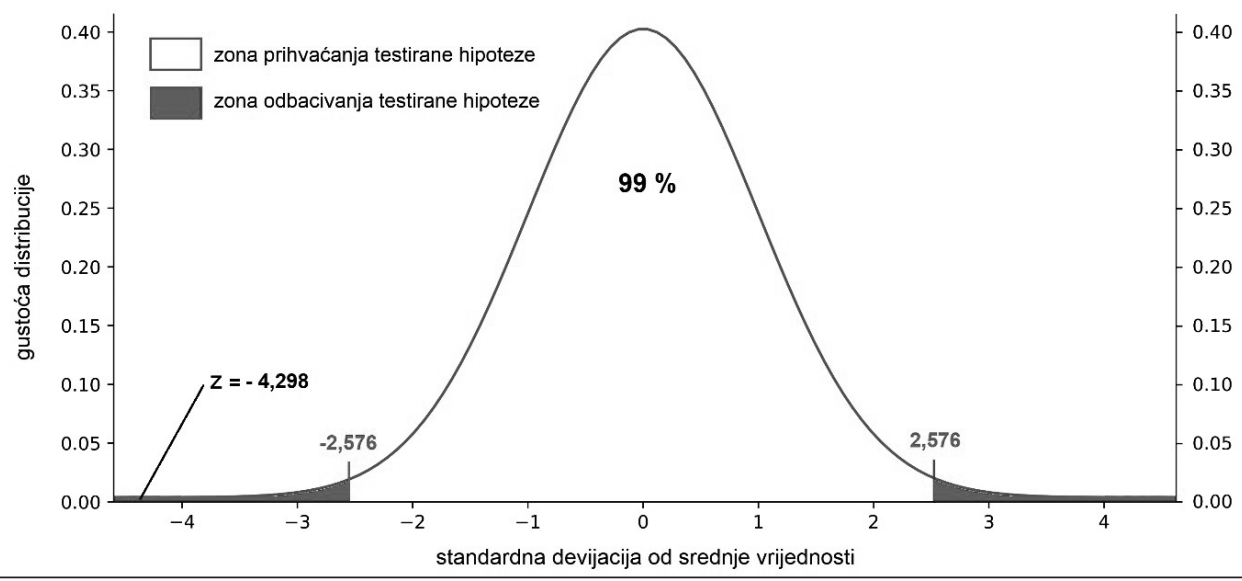

Izvor: anketa

Rezultati z-testa ukazuju na potrebu odbacivanja nul-hipoteze, odnosno prihvaćanje alternativne hipoteze, koja kaže da postoji statistički značajna razlika između urbane i ruralne populacije učenika po pitanju njihove percepcije utjecaja javne rasvjete i reklama na svjetlosno onečišćenje u okolišu u kojem žive. 
Kako bi se dalje jednoznačno utvrdili razlozi razlika između percepcije svjetlosnog onečišćenja i stavova prema problematici kod urbane i ruralne populacije, potrebno je provesti daljnja komparativna istraživanja na razini studija slučaja manjih ruralnih i urbanih područja. Kako bi istraživanja imala svojstvo objektivnosti, bilo bi potrebno primarno mjerenjima utvrditi stanje u okolišu po pitanju svjetlosnog onečišćenja te nakon toga provesti anketiranje upitnikom prilagođenim za mjerenje razlika u osjetljivosti na svjetlosno onečišćcenje, stavovima i spremnosti na prevenciju svjetlosnog onečišćenja.

\section{Zaključak}

U trenutku u kojem živimo na globalnoj, ali i lokalnoj razni sve su vidljiviji negativni utjecaji ljudskog djelovanja na okoliš. Kvaliteta i očuvanje okoliša sigurno je jedna od najvažnijih tema današnjice, a odgovornost s kojom pristupamo očuvanju životnog prostora očituje se u trenutnoj kvaliteti života kao i posljedicama koje ćemo kao društvo tek snositi u budućnosti. Kompleksnost antropogenim djelovanjem izmijenjenog okoliša tolika je da je teško istovremeno proučavati sve elemente i čimbenike te aspekte zaštite okoliša. $U$ ovom je radu izdvojen dio problematike svjetlosnog onečišćenja, kojim čovjek djeluje na svoju životnu sredinu i ukupni okolišs. Istraživanjem, analizom i interpretacijom rezultata ovim je radom izloženo stanje po pitanju poznavanja problematike, svjesnosti i stavova učenika gimnazijskih programa u Hrvatskoj po pitanju svjetlosnog onečišćenja.

Prostorne su razlike u opremljenosti i kvaliteti komunalne infrastrukture u Hrvatskoj velike te se odražavaju i u aspektu svjetlosnog onečišćenja ne samo na regionalnoj već i na lokalnoj razini. Stoga analiza rezultata ovog istraživanja nije ciljana ka usporedbi stanja u prostoru koje je posljedica razlika u javnoj rasvjeti, već se ciljalo na poznavanje problematike, te su izdvojeni subjektivni stavovi i percepcije ispitanika prema utjecaju svjetlosnog onečišćenja na okoliš.

Rezultati su pokazali da ne postoje veće regionalne razlike u poznavanju problematike i stavovima o svjetlosnom onečišćenju, odnosno vidljiva je homogenost ispitanika na nacionalnoj razini. Vidljivo je da učenici na nacionalnoj razini razlikuju rasvjetna tijela prema njihovom utjecaju na stvaranje svjetlosnog onečišćenja. Bez obzira na visoku razinu znanja o razlikovanju rasvjetnih tijela koja stvaraju svjetlosno onečǐsćenje, potpuno je suprotna situacija po pitanju znanja učenika o tome kome bi mogli/ trebali prijaviti primjere svjetlosnog onečišćenja. Učenici su na nacionalnoj razini također svjesni teoretskog utjecaja svjetlosnog onečišćenja na okoliš i ljude, ali kada je u pitanju osobni stav prema konkretnom utjecaju javne rasvjete i reklama na njihov san, potvrdan je odgovor dalo tek oko trećine ispitanika. Kad je u pitanju spremnost učenika na djelovanje po pitanju smanjenja javne rasvjete i svjetlećih reklamnih tijela, učenici su bili višeg stupnja potpore za regulaciju, a nešto nižeg stupnja potpore za opciju potpunog gašenja javne rasvjete i reklama. 
Rezultati usporedbe učenika iz ruralnih i urbanih prostora po pitanju svjesnosti o utjecaju svjetlosnog onečišćenja na okoliš pokazuju da između ovih dvaju prostornih skupina učenika ne postoje veće razlike te da je opća svijest o utjecaju svjetlosnog onečišćenja na okoliš relativno visoka. Usporedba učenika iz ruralnih i urbanih prostora po pitanju proaktivnosti, odnosno spremnosti na gašenje ili smanjivanje svjetlosnog onečišćenja tijekom noćnih perioda, pokazuje da između ovih dvaju prostornih skupina učenika ne postoje veće razlike te da je opća spremnost na djelovanje u zaštiti okoliša od svjetlosnog onečišćenja visoka.

Ipak, uočene su i određene razlike kao posljedica obilježja prostora u kojem ispitanici žive, odnosno utvrđene su razlike između urbane i ruralne populacije učenika po pitanju procjene utjecaja svjetlosnog onečišćenja na okoliš. Tako primjerice učenici iz urbanih područja procjenjuju da je utjecaj svjetlosnog onečišćenja na okoliš neutralan ili malen, za razliku od učenika iz ruralnih područja, koji su više skloni procijeniti utjecaj svjetlosnog onečišćenja u svom okolišu u kategoriji malog i vrlo malog utjecaja. Iz navedenog bi se moglo zaključiti da javna rasvjeta u ruralnim prostorima svjetlosno manje onečišćuje okoliš te posljedično učenici procjenjuju da je utjecaj svjetlosnog onečišćenja u njihovom životnom prostoru manji. Također, opisana razlika između ispitanika mogla bi biti i posljedica višeg stupnja izvornosti okoliša i posljedično manjoj usredotočenosti na problematiku onečišćenja okoliša te percepcije svjetlosnog onečišćenja.

S obzirom na nisku razinu istraženosti problematike svjetlosnog onečišćenja u Republici Hrvatskoj i velikih razlika u komunalnoj opremljenosti prostora te kvaliteti rasvjetnih tijela u izvedbi javne rasvjete, ovim istraživanjem nije bilo predviđeno ponuditi pregled stanja u prostoru ili rješenja predmetne problematike, već ukazati na razlike u stavovima i percepciji osoba. Kao što je ranije opisano u interpretaciji rezultata, u daljnjim je istraživanjima potrebno, uz korištenje multidisciplinarnog pristupa, otvarati nove uže teme i oblikovati istraživanja na razini studija slučaja svjetlosnog onečišćenja na lokalnim razinama, koje mogu dati konkretan doprinos u planiranju i oblikovanju vizualno atraktivnog, sigurnog, ugodnog i zdravog životnog prostora.

\section{Zahvala}

Zahvaljujemo svim školama, kolegama i učenicima koji su uložili svoje slobodno vrijeme i entuzijazam kako bi omogućili, proveli i sudjelovali u anketiranju za potrebe ovoga istraživanja. Nadamo se da će njihov trud otvoriti neke nove istraživačke teme, osvijestiti važnost zaštite od svjetlosnog onečišćenja i svima nama donijeti ugodniji, ljepši i zdraviji okoliš. 


\section{Literatura}

1. Andreić, Ž.; Korlević, K.; Andreić, D.; Bonaca, A.; Korlević, P.; Kramar, M. (2011). Svjetlosno onečišćenje u Republici Hrvatskoj. Gradevinar, 63: 757-764.

2. Andreić, Ž.; Andreić, D. i Pavlić, K. (2012). Near infrared light pollution measurements in Croatian sites. Geofizika, 29: 143-156.

3. Andreić, Ž. (2018). Night sky brightness above Zagreb - Croatia 2012-2017. The Mining-Geology-Petroleum Engineering Bulletin, 33 (3): 85-94.

4. Carlsen, L. and Bruggemann, R. (2020). Environmental perception in $33 \mathrm{Eu}-$ ropean countries: an analysis based on partial order. Environment, Development and Sustainability, 22 (3): 1873-1896.

5. Chepesiuk, R. (2009). Missing the Dark: Health Effects of Light Pollution. Environmental Health Perspectives, 117 (1): A20-A27.

6. Coogan, A. N.; Cleary-Gaffney, M.; Finnegan, M.; McMillan, G.; González, A.; Espey, B. (2020). Perceptions of Light Pollution and its Impacts: Results of an Irish Citizen Science Survey. International journal of environmental research and public health, 17 (15): 5628.

7. Lima, R. C.; Pinto da Cunha, J. and Peixinho, N. (2016). Light pollution: Assessment of sky glow on two dark sky regions of Portugal. Journal of Toxicology and Environmental Health, Part A, 79 (7): 307-319.

8. Doll, C. N.; Muller, J. P. and Morley, J. G. (2006). Mapping regional economic activity from night-time light satellite imagery. Ecological Economics, 57 (1): 75 92.

9. Falchi, F.; Cinzano, P.; Elvidge, C.D.; Keith, D. M.; Haim, A. (2011). Limiting the impact of light pollution on human health, environment and stellar visibility. Journal of Environmental Management, 92: 2714-2722.

10. Fonović, M. (2008). Svjetlosno onečišćenje - Kamo su nestale zvijezde?. Zaštita okoliša, 57 (1): 27-32.

11. Fuk, B. (2019). Svjetlosno onečišćenje. Sigurnost: časopis za sigurnost u radnoj $i$ životnoj okolini, 61 (4): 401-405.

12. Gaston, K. J.; Davies, T. W.; Bennie, J.; Hopkins, J. (2012). Reducing the ecological consequences of night-time light pollution: options and developments. Journal of Applied Ecology, 49: 1256-1266.

13. Gaston, K. J.; Bennie, J.; Davies, T. W.; Hopkins, J. (2013). The ecological impacts of nighttime light pollution: a mechanistic appraisal. Biological reviews, 88 (4): 912-927.

14. Grofelnik, H. (2019). Svjesnost i stavovi srednjoškolske i studentske populacije o problemu svjetlosnog onečišćenja, u: Cattunar, A. (Ur.). Prvi znanstvenostručni kongres s medunarodnim sudjelovanjem "Svjetlosno onecišćéenje“. Rijeka: Nastavni zavod za javno zdravstvo Primorsko-goranske županije.

15. Hölker, F.; Wolter, C.; Perkin, E. K.; Tockner, K. (2010). Light pollution as a biodiversity threat. Trends in ecology and evolution, 25 (12): 681-682. 
16. Hölker, F.; Moss, T.; Griefahn, B.; Kloas, W.; Voigt, C.; Henckel, D.; Hänel, A.; Kappeler, P.; Völker, S.; Schwope, A.; Franke, S.; Uhrlandt, D.; Fischer, J.; Klenke, R.; Wolter, C.; Tockner, K. (2010). The dark side of light: a transdisciplinary research agenda for light pollution policy. Ecology and Society, 15 (4): Art13.

17. Krajnović, A. (2020). Astroturizam--u traganju za novim prostorima i imaginacijom u turizmu. Sociologija i prostor, 58 (3): 329-355.

18. Krajnović, A. (2020). Astroturizam kao selektivni oblik turizma: konceptualni okvir. Acta Economica Et Turistica, 6 (1-2), 41-62.

19. Longcore, T. and Rich, C. (2004). Ecological light pollution. Frontiers in Ecology and the Environment, 2 (4): 191-198.

20. Narisada, K. and Schreuder, D. (2004). Light pollution handbook. New York: Springer.

21. Navara, K. J. and Nelson, R. J. (2007). The dark side of light at night: physiological, epidemiological, and ecological consequences. Journal of pineal research, 43 (3): 215-224.

22. Martinis, M. i Mikuta-Martinis, V. (2008). Život pod umjetnom rasvjetom i zdravlje. Sigurnost, 50 (2): 97-103.

23. Metaxa, M. (2010). Astronomy Education: a challenge for contemporary Education, in: Kanaris Tsinganos; Despina Hatzidimitriou and Titos Matsakos (Eds.). $9^{\text {th }}$ International Conference of the Hellenic Astronomical Society. Athens: Hellenic Astronomical Society.

24. Mizon, B. (2002). Light Pollution: Responses and Remedies. New York: Springer.

25. Özyürek, C. and Aydin, G. (2015). Students' Opinions on the Light Pollution Application. International Electronic Journal of Elementary Education, 8 (1): 5568.

26. Pavlić, K. i Andreić, Ž. (2020). Usporedba svjetline noćnoga neba iznad Zagreba i iznad bliske ruralne lokacije za razdoblje od 2014. do 2017. Rudarskogeološko-naftni zbornik, 35 (2): 45-55.

27. Percy, J. R. (2001). Light Pollution: Education of Students, Teachers and the Public. Symposium-International Astronomical Union. 196: 353-358

28. Riegel, K. W. (1973). Light Pollution. Science, 179: 1285-1291.

29. Sharma, I.; Mostečak, A. i Andreić, Ž. (2015). Svjetlosno onečišćenje grada Zagreba u periodu prosinac 2010. - srpanj 2011. Rudarsko-geološko-naftni zbornik, 30: 9-17.

30. Teikari, P. (2007). Light pollution: definition, legislation, measurement, modeling and environmental effects. Barcelona: Universitat Politècnica de Catalunya.

31. Zakon o zaštiti od svjetlosnog onečišćenja, Narodne novine 14 od 2019.

32. Pravilnik o zonama rasvijetljenosti, dopuštenim vrijednostima rasvjetljavanja i načinima upravljanja rasvjetnim sustavom, Narodne novine 128 od 2020. 


\title{
Sensitivity of Croatian High School Students to Light Pollution
}

\author{
Hrvoje Grofelnik \\ University of Rijeka, Faculty of Tourism and Hospitality Management, Opatija, Croatia \\ e-mail: hrvoje.grofelnik@fthm.hr
}

Marko Miočić

First Rijeka Croatian Grammar School, Rijeka, Croatia

e-mail: marko.miocic1@skole.hr

Tomislav Golubić

Vladimir Prelog School of Science, Zagreb, Croatia

e-mail: tomislav.golubic11@skole.hr

\begin{abstract}
This paper is the result of a national level survey on the state of knowledge, awareness and attitudes of high school students in Croatia towards the problem of light pollution. Differences in communal infrastructure in Croatia are large, and also reflected in the aspect of light pollution. The conducted research was not aimed at comparing the situation in environment regarding light pollution, but at knowing the issues, subjective attitudes and perceptions of high school students towards the impact of light pollution on the environment. To obtain the most objective insight, the research is based on quantitative methods, and the results are presented and interpreted with the help of descriptive and inductive statistics.

The results show the homogeneity of the respondents at the national level, in their knowledge of the issues, awareness and attitudes on light pollution. The comparison of students from rural and urban areas, in terms of light pollution awareness, showed that there were no major differences, and that the general awareness is relatively high. The comparison of students from rural and urban areas, in terms of light pollution prevention, also shows that there are no major differences and that the readiness to act is high. However, some differences were also observed between the urban and rural student populations in terms of assessing the impact of light pollution on the environment. Students from urban areas estimate that the impact of light pollution on the environment is neutral or small, in contrast to students from rural areas who are more inclined to assess the impact in the category of small and very small.
\end{abstract}

Key words: sustainable development, environment, environmental protection, light pollution, education, grammar school. 